\title{
掘削および構築時の支持地盤のヤング係数の変化 YOUNG'S MODULI OF BEARING STRATA ESTIMATED FROM VERTICAL DEFORMATION DURING EXCAVATION AND CONSTRUCTION
}

\author{
玉置克之*, 桂 豊**, 岸田了*** \\ Katsuyuki TAMAOKI, Yutaka KATSURA and Satoru KISHIDA
}

\begin{abstract}
A process for obtaining reliable Young's moduli of bearing soil strata $(E)$ is discussed in this paper. The process is based on measurements of vertical strain $\left(\varepsilon_{v}\right)$ of bearing strata during excavation and building construction. $E$ for settlement analyses must be determined based on the relation between $E / E_{0}^{\prime}$ and $\varepsilon_{v}$ during construction, where $E_{0}^{\prime}$ is the Young's modulus after excavation, which in turn is calculated from the Young's modulus $E_{0}$ from shear wave velocity before excavation. The relation between $E / E_{0}$ and $\varepsilon_{v}$ during excavation is not equal to the relation between $E / E_{0}^{\prime}$ and $\varepsilon_{v}$ in that $\mathrm{E}$ depends on both $\varepsilon_{v}$ and stress level in the soil.

Keywords : Young's modulus, bearing stratum, mat foundation, settlement, velocity of $S$-rwave, differential settlement gauge

ヤング率，支持層，べた基礎，沈下， $S$ 波速度，層別沈下計
\end{abstract}

1.はじめに

直接基礎の即時沈下の計算は，一般に支持地盤を弾性 体と仮定して行われている。この場合, 支持地盤のヤン グ係数をよ゙のように設定するかが重要な問題である。

構造物の沈下の測定に基づいた支持地盤のヤング係数 の推定方法に関する従来の研究により, 標準貫入試験に よる $N$ 值からの推定法 ${ }^{112)}$ や硬質粘土層に対する孔内水 平載荷試験の適用性 なよ゙が報告されている。最近では 高層ビルなどにおける施工時の実測から, 笹尾 ${ }^{4)}$, 玉野 $ら^{5)}$, 秋野6)および筆者ら ${ }^{71,8)}$ により実測によるヤング係 数とPS 検層から求めたヤング係数との関係や, 実測によ るヤング係数とひずみとの関係について報告されている。

また, 建築基礎構造設計指針には, 砂試料の繰返しせ ん断試験で得られたせん断ひずみとせん断剛性の関係を 利用して, PS 検層などのせん断波速度 Vsによる微小 ひずみ時のヤング係数 $E_{0}$ を低減する方法" が提案され ている。しかし，その適用性についてはあまり明確になっ ていないのが現状である。せん断波速度試験は, 孔内水 平載荷試験や標準貫入試験などの他の試験とは異なり非 破壊試験であるので, 試験から求まるせん断波速度 Vs は他の試験值に比べて信頼性が高い。Vsから求めた微 小ひずみ時のヤング係数 $E_{0}$ を施工時の地盤に生ずるひ
ずみや拘束圧などの条件にあった適切な値に低娍する方 法が明確にできれば，Vsに基づいた推定方法は最も合 理的な方法であろうと考えられる。

筆者らは，施工時の支持地盤に生ずる鉛直変位を正し く測れるように工夫した新しい層別沈下計を作製し，直 接基礎により洪積層に支持された四つの建物の施工時に 鉛直変位の测定を行った。これらの測定結果から，せん 断波速度による微小ひずみ時のヤング係数 $E_{0}$ を低減し て用いるのが他の調查による方法に比べて地盤のヤング 係数の推定に対する適用性が高いものと考えられた

本論文では, 四つの建物のうち掘削平面の中央部と端

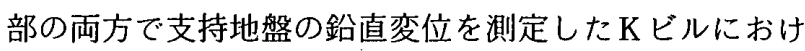
る测定結果を主に示し，測定した地盤の鉛直変形量から 求めた地盤のヤング係数 $E$ と $V$ から求めた $E_{0}$ の比 $E / E_{0}$ の性状に関して, 地盤の鉛直ひずみ $\varepsilon_{v}$ および地 中応力との関係, 掘削時と建物構築時の違い, 掘削平面 の中央部と端部の違いなどについで述べた。

\section{2. 支持地盤の鉛直変位の测定}

\section{1 鉛直変位の測定方法}

従来は地盤の鉛直変位を地層別に測定するのに，先端 の深さを変えて設置した複数の二重管式沈下計を用いる

\footnotetext{
* 清水建設 (株) 技術研究所 主席研究員・工修 Chief Research Engineer, Institute of Technology Shimizu Corp., M. Eng.

** 清水建設 (株) 技術研究所 主任研究員

*** 清水建設 (株) 技術研究所 研究員・工修 
ことが多かった。しかし，この方法には，施工中に測定 点の盛替えが必要である, 多数の管が施工の障害になる 測定に光学レベルを用いるので測定の精度が悪いなどの 問題があったため, 最近は電気式変位計を用いた様々な 形式の層別沈下計により測定することが多くなってい る。しかし，変位を正しく測定するには変位計の精度に 加えて, 沈下計の構造や設置方法についても十分な配慮 が必要である。特に支持地盤の変位測定のような微小変 位の測定では, 内管と外管の競りや, 変位計と地盤との 一体化が不十分であることなどが測定值に大きな影響を 与えるものと考えられる。

支持地盤の鉛直変位測定のために新しく考案し，作製 した層別沈下計を図一1に示した10)。作製した層別沈下 計の主な特徵はつぎのとおりである。

(a) 各区間の地盤の変形量を, 各区間の上端部に設置 した変位計で区間別に測定する新しい形式であり，区間 別に測定する点で従来のものより測定の精度がよい。

（b）地盤之内管との縁切りに蛇腹式の外管を採用して おり，外管が地盤の変位を拘束しない。

(c) 変位計の地盤への定着はアンカーによるほか, 地 盤と外管の間にベントナイトモルタルを注入してより完 全にしている。

（d）外管と内管の間は沈下計の先端部から地上部まで 空腺が連続しており，外管の周囲のベントナイトモルタ ルがほぼ硬化した時点で先端から送水して，空隙部分を 十分洗净することができる。このため，仮に侵入した土 砂やベントナイトモルタルが空隙部分にあっても最終的 には残置することがなく,内管と外管に競りを生じない。

2.2 測定内容

掘削平面の中央部と端部で支持地盤の鉛直変位の測定

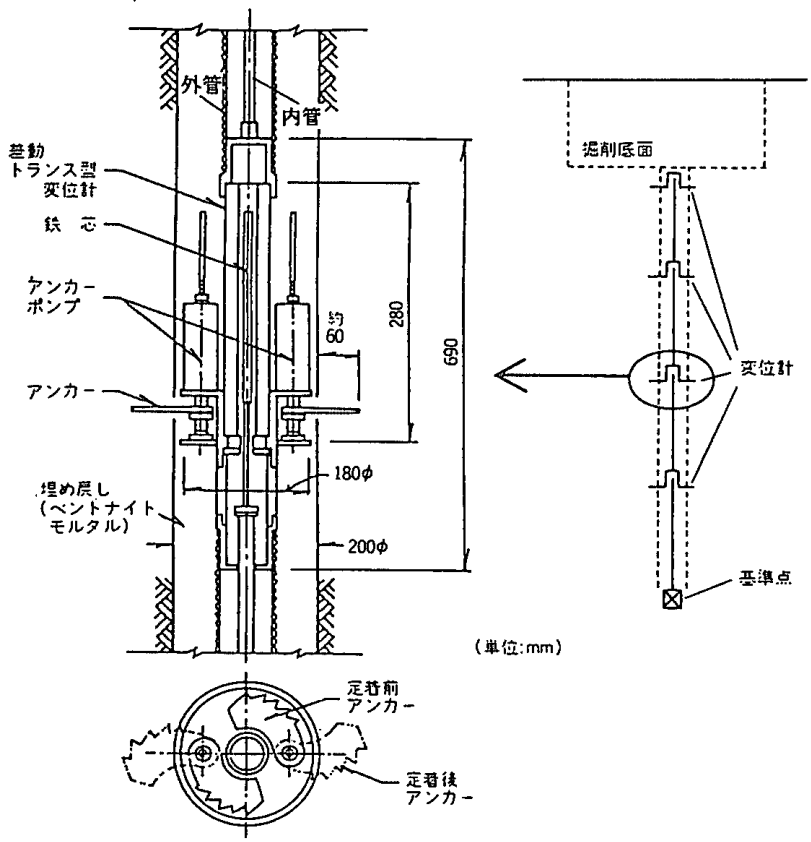

図一1＼cjkstart層別㶩下計詳細図

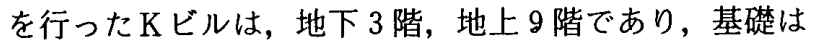

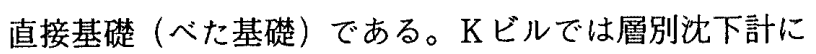
よる支持地盤の鉛直変位の測定に加え, 中央部では層別 沈下計の各変位計の部分に加速度計を取り付けて設置 し，板吒き法により各掘削段階ごとに支持地盤のせん断

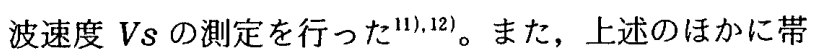
水層の間隙水圧の測定, および掘削底面に土圧計を設置 して建物構築時の接地圧分布の測定も行った。

図一2 は, Kビルの平面であり, 図中に層別沈下計, 間隙水俚計, 土圧計の配置, および PS 検層を行った事 前調查の位置を示した。また, 図一 3 には, Kビルの地 盤断面之事前調查による $N$ 値およびPS 検層によるせ ん断波速度 Vs の分布, 層別沈下計および掘削時のせん 断波速度測定のための加速度計の設置深度, 間隙水圧計 の設置深度, 掘削深度を示した。

地盤は GL-10 m までが比較的柔らかなロームおよび 粘土層である。直接基礎は GL-14.3 m の洪積粘土層に 支持されている。洪積粘土層の Vs は約 $230 \mathrm{~m} / \mathrm{sec}$, 圧 密降伏応力は約 $50 \mathrm{tf} / \mathrm{m}^{2}$ である。

支持地盤の鉛直変位の測定は, 掘削平面の中央部と端 部から $4 \mathrm{~m}$ 離れた地点の 2 か所で行い, いずれも GL-35 m を基準点とし, 基礎底面下の粘土層, 砂層 (上 部), 磉混り砂層, および砂層（下部）の各層について 測定した。

\section{3. 鉛直変位の測定結果}

施工時の支持地盤の地下水圧, 土圧計による接地圧の

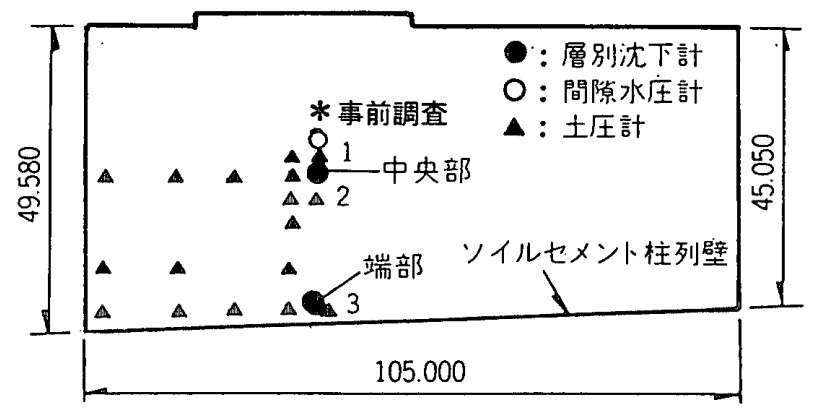

図一2 計器配置図

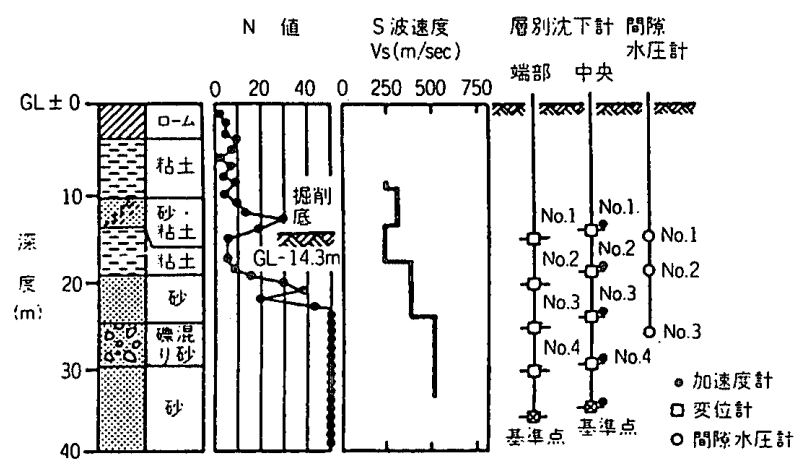

図一3 地盤断面および計器設置深度 
測定值，および層別沈下計による各層の鉛直変形量の経 時変化を図一 4 に示した。地下水位は粘土層の上部で掘 削時に約 $3 \mathrm{~m}$ 低下しているほかは変化していない。最 終時の接地圧は 10 11 $\mathrm{tf} / \mathrm{m}^{2}$ であり, 建物荷重による平 均接地圧（約 $10 \mathrm{tf} / \mathrm{m}^{2}$ ) に近い值になっている。各層の 鉛直変形は掘削時は膨張し,構築時は珐縮に転じている。

図一5.(a).は，層別沈下計の先端を基準にした，掘削 開始から終了するまで掘削期間の変位量, および掘削終 了後から構築が終了するまでの構築期間の変位量の分布
である。掘削底面から下の $20 \mathrm{~m}$ の全測定区間における 掘削期間の変形量の総計は中央部が約 $14 \mathrm{~mm}$, 端部が 約 $11 \mathrm{~mm}$ であり，構築期間の変形量の総計はいずれも 約 $7 \mathrm{~mm}$ であった。図一5(b) は，図一5(a) の各層の変 形量を層厚で除して求めた掘削および構築期間に生じた 鉛直ひずみ $\varepsilon_{v}$ の分布である。 $\varepsilon_{v}$ は掘削底面から離れる ほどいずれも小さくなっている。底面付近の粘土層の $\varepsilon_{v}$ は掘削時が $1.5 \times 10^{-3}$, 構築時はその約 $1 / 2$ であり, $10 \mathrm{~m}$ 以深の碩混り砂層および砂層（下部）の $\varepsilon_{v}$ はいず

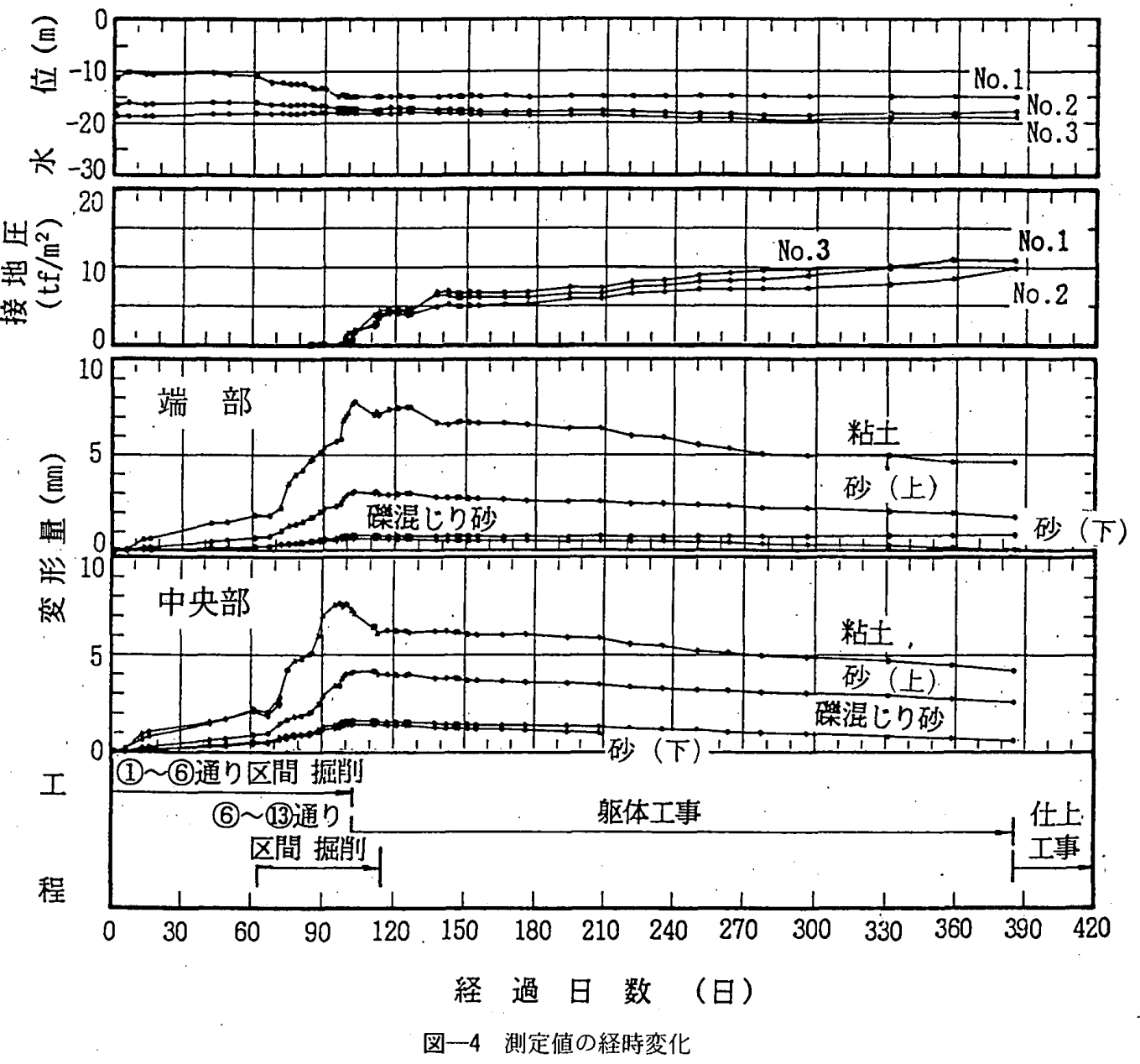

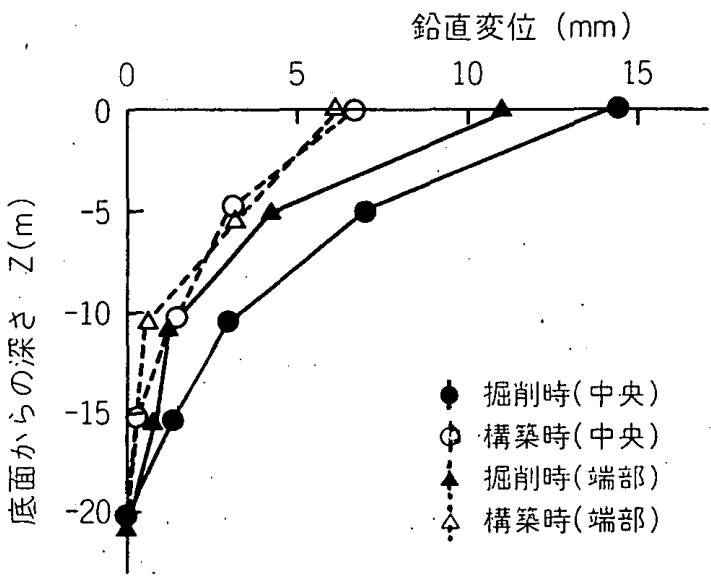

(a) 鉛直変位分布

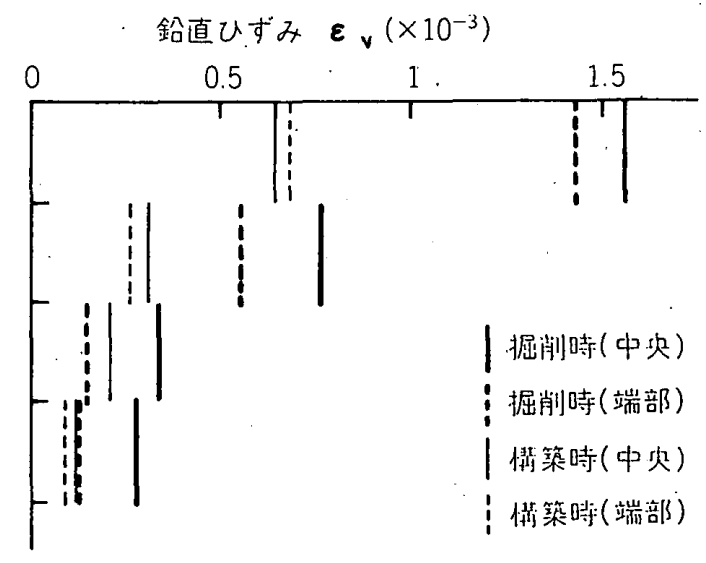

（b）鉛直ひずみ分布

図一5 鉛直変位と鉛直ひずみの分布 

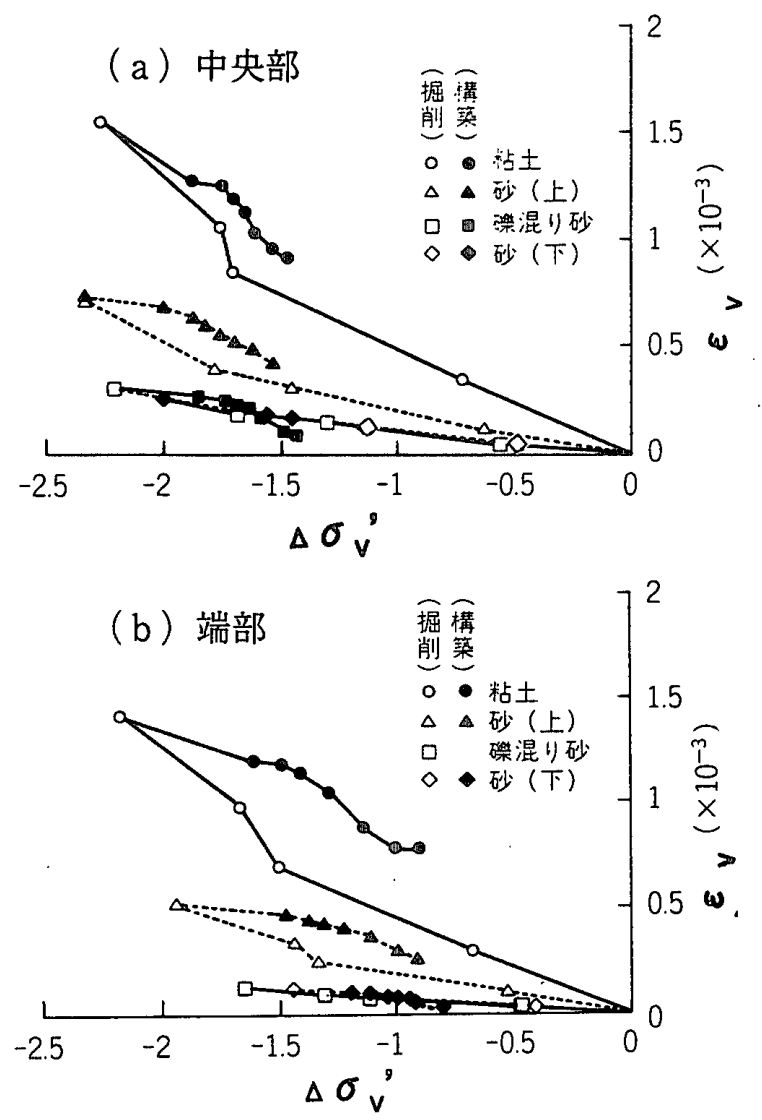

図一6 鉛直応力と鉛直ひずみの関係

れも $0.5 \times 10^{-3}$ 以下である。

掘削および構築による各層の中間深度の鉛直有効応力 の変化量 $\Delta \sigma_{v}^{\prime}$ と, 各層の変形量を層厚で除して求めた 鉛直ひずみ $\varepsilon_{v}$ の関係を示したのが図一6である。 $\Delta \sigma_{v}^{\prime}$ は地盤内の鉛直応力の変化量 $\Delta \sigma_{v}$ と間腙水圧の変化量 $\Delta u$ とから算出した值である。なお, 掘削時の地盤内の $\Delta \sigma_{v}$ は掘削初期からの排土重量を掘削底面に載荷し, 構 築時の $\Delta \sigma_{v}$ は各時点の建物の重量と土圧計による接地 圧分布とから設定した荷重分布を掘削底面に載荷し，い ずれも長方形分割法により求めた。 $\Delta \sigma_{v}^{\prime}$ と $\varepsilon_{v}$ の関係は 掘削時と構築時では異なっている。また， $\varepsilon_{v}$ が $1 \times 10^{-3}$ 以下の鉛直ひずみにおいても非線形性を示している。

\section{4. 鉛直変位から求めた地盤のヤング係数}

\section{1 ヤング係数の計算方法}

支持地盤の応力とひずみの関係は図一6のように非線 形な関係を示す。しかし，基礎の即時沈下は地盤を等方 弾性体と見なして弾性論により求めることが多い。この 方法は，計算が簡便であり，地盤定数設定の精度や解析 において考慮できる条件などからみて現実的な方法であ ると考えられる。層別沈下計により测定した各層の鉛直 変形量 $\delta$ からの地盤のヤング係数の算出も, 同じよう に弾性論により行うこととした。

鉛直変形量 $\delta$ から弾性論によりヤング係数を求める 手順は図一7に示したとおりである。まず，掘削時は掘

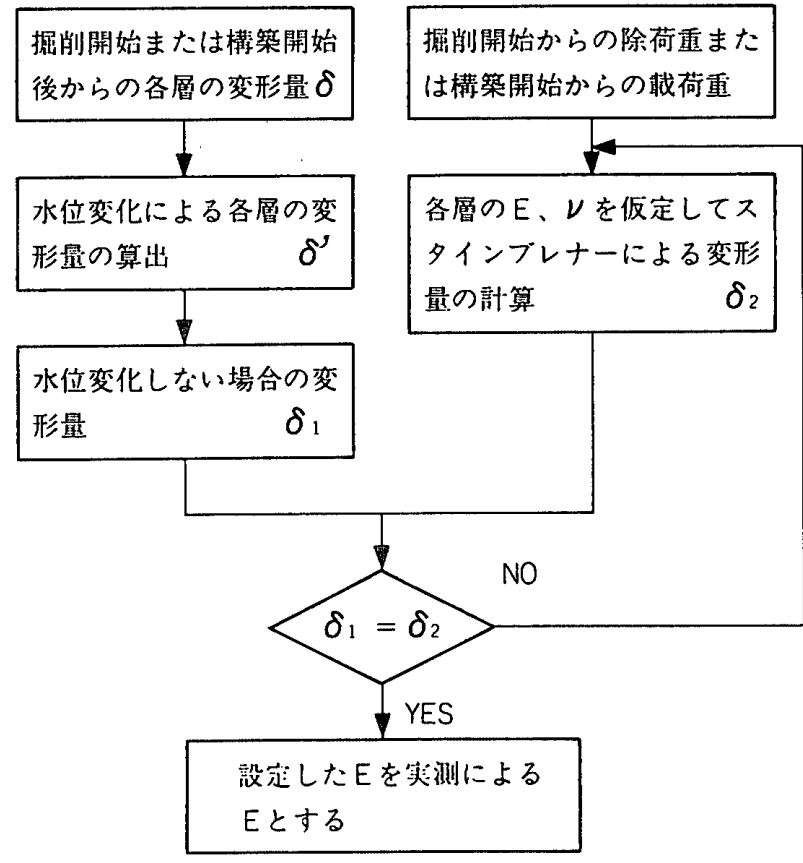

図一7測定結果からのヤング係数の計算手順

削開始時, 同様に構築時は構築開始時点を初期値とした 各時点までの変形量 $\delta$ から水位変位による地盤の変形 量 $\delta^{\prime}$ を差し引いた, 水位変化しないときの変形量 $\delta_{1}$ を 求める。つぎに, 各層のヤング係数とポアンン比を仮定 し, 掘削時は各時点までの排土重量を, 構築時は土圧計 による接地圧の測定結果に基づいた分布荷重を掘削底面 に載荷して変形量 $\delta_{2}$ を求める。このときの計算にはス タインブレナーの弾性近似解 ${ }^{13)}$ を用いた。また, 地盤の ポアソン比 $\nu は$, 建築基礎構造設計指針1)に述べられた 值を参考にして,地盤の種類別に常に次の值を仮定した。

砂質土層 $\quad \nu=0.35$

砂磜層 $\quad \nu=0.3$

粘性土層 $\quad \nu=0.45$

ヤング係数を変えた繰返し計算を行い， $\delta_{1}$ と $\delta_{2}$ とが等 しくなったときのヤング係数の仮定値を実測によるヤン グ係数 $E$ とした。なお，水位変化による地盤の変形量 $\delta^{\prime}$ は, 有効応力の変化により地盤が一次元圧縮または 膨張するものとして, 前の段階の計算において求めた $E$ を用いて計算した。

\section{2 支持地盤のヤング係数}

図一7の方法によって求めた掘削時の鉛直変位の実測 值に基づくヤング係数 $E$ と，ヤング係数を求めた時点 の各層の変形量を層厚で除して求めた鉛直ひずみ $\varepsilon_{v}$ の 関係を図一8 (a) に示した。同様に, 構築時の $E$ と $\varepsilon_{v}$ の関係を図一8(b) に示した。

また，鉛直変位の実測値から求めたヤング係数 $E$ と 微小ひずみ時のヤング係数 $E_{0}$ の比 $E / E_{0}$ （以下ヤング 係数比と呼ぶ）と $\varepsilon_{v}$ の関係を, 図一 $9(\mathrm{a})$ および (b) に示した。ここで， $E_{0}$ は掘削前に行ったPS 検層によ 
る地盤のせん断波速度 $V s_{0}$ から式（1）により求めた

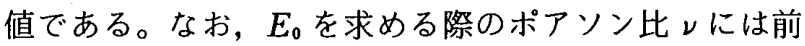
述の值を用いた。

$$
E_{0}=2(1+\nu) \gamma \cdot V s_{0}^{2} / g \cdot
$$

ここに， $\gamma:$ 地盤の単位体積重量 $g:$ 重力加速度

図一9によれば，掘削時および建物構築時ともに $\varepsilon_{v}$
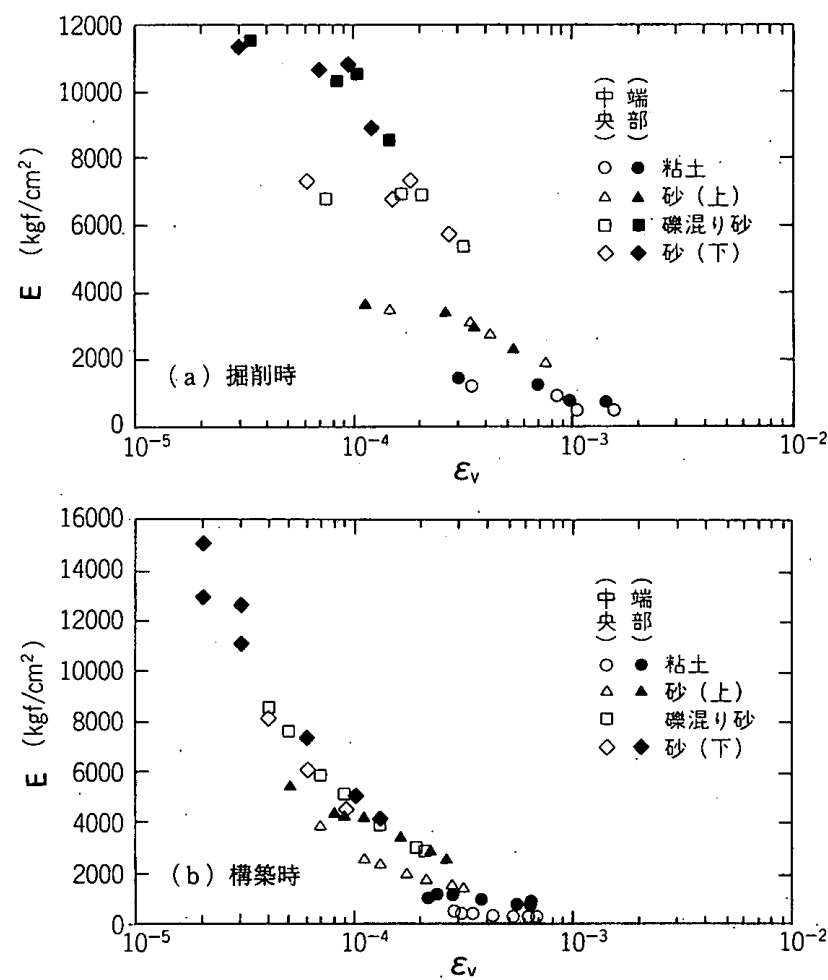

図一8 ヤング係数と鉛直ひずみの関係
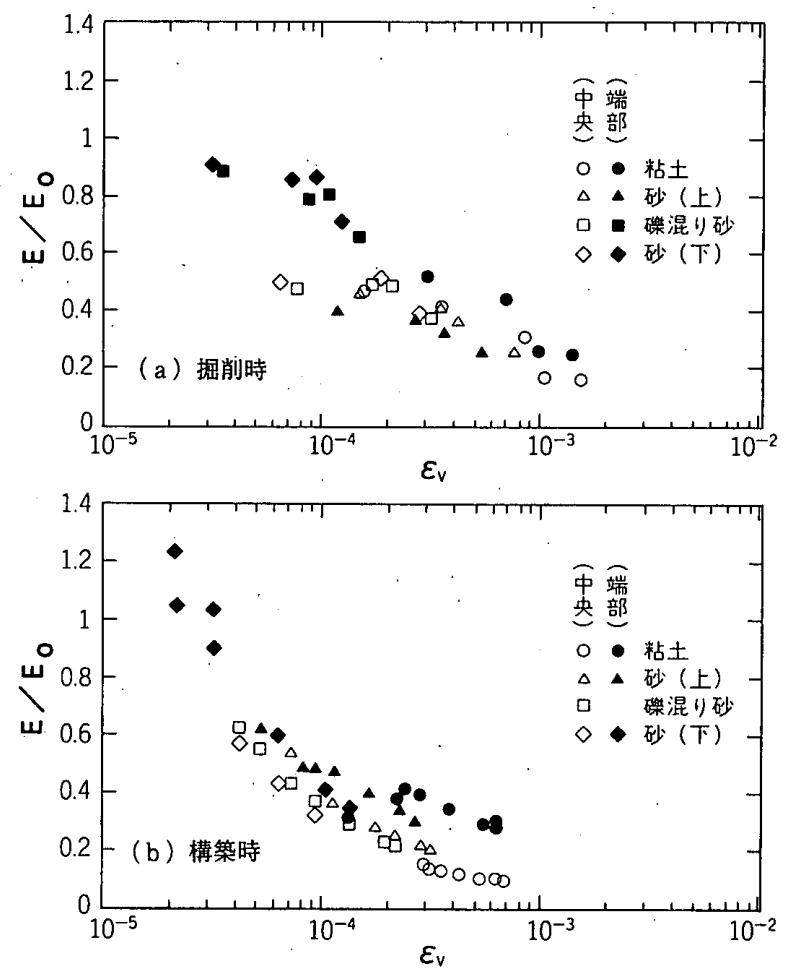

図一9 ヤング係数比と鉛直ひずみの関係
の増加によりヤング係数比 $E / E_{0}$ は減少しており, $E / E_{0}$ と $\varepsilon_{v}$ は地盤の種類や深さによらずほぼ一定な関 係を示している。しかし，掘削時は $\varepsilon_{v}$ が増すにつれて 片対数グラフ上で $E / E_{0}$ の低下率が増す傾向があるが， 構築時は徐々に低下率が減少する傾向があり, $E / E_{0}$ と $\varepsilon_{v}$ の関係は掘削時と構築時では異なっている。

中央部と端部の違いについてみると，図一9(a) の掘 削時は，底面直下の粘土では端部が中央部より少し大き く, 砂層（上部）では逆になっている。また，底面から $10 \mathrm{~m}$ 以深の礫混り砂層と砂層 (下部) の中央部と端部 の差が $\varepsilon_{v}<1 \times 10^{-4}$ の部分で大きいなよ゙，中央部と端部 の違いの傾向は明確でない。一方, 図一 $9($ b $)$ ，の構築時 は, 底面直下の粘土層, 砂層 (上部), 砂層 (下部) と もに端部が中央部より大きな值となっている。

\section{5. 掘削および構築時のヤング係数比の性状}

\section{1 地中応力の解析}

層別沈下計に取付けた加速度計により掘削段階ごとに 測定したせん断波速度 Vs と地中応力の関係，および中 央部と端部のヤング係数比 $E / E_{0}$ の違いと地中応力と の関係の検討のために, 2 次元 FEM 解析を実施し, 各 掘削時点の地中応力を求めた。

図一10は獬析モデルである。図中には各掘削段 階における掘削深度も示した。地中応力計算時の各層の ヤング係数には掘削終了時の建物平面の中央部の $\varepsilon_{v}$ か ら図一7の方法により算出したヤング係数を用いた。ま た, ポアソン比 $\nu$ は前述の值（粘土：0.45, 砂: 0.35 , 磁混り砂：0.3）とした。なお, 各層の初期の静止土王 係数 $K_{0}$ は, 粘土層の圧密試験による過圧密比が 2.5 で あることを参考に，すべての地層について $K_{0}=1$ と仮 定した。予備解析の結果から，Kビルの場合は山留め壁 の剛性および壁と地盤の摩擦係数の大きさが地中応力に ほとんど影響を及ぼさないことが分かっている ${ }^{14)}$

上述の仮定により計算した，各掘削段階における鉛直 有効応力 $\sigma_{v}^{\prime}$ と, 鉛直および水平 2 方向の平均有効応力

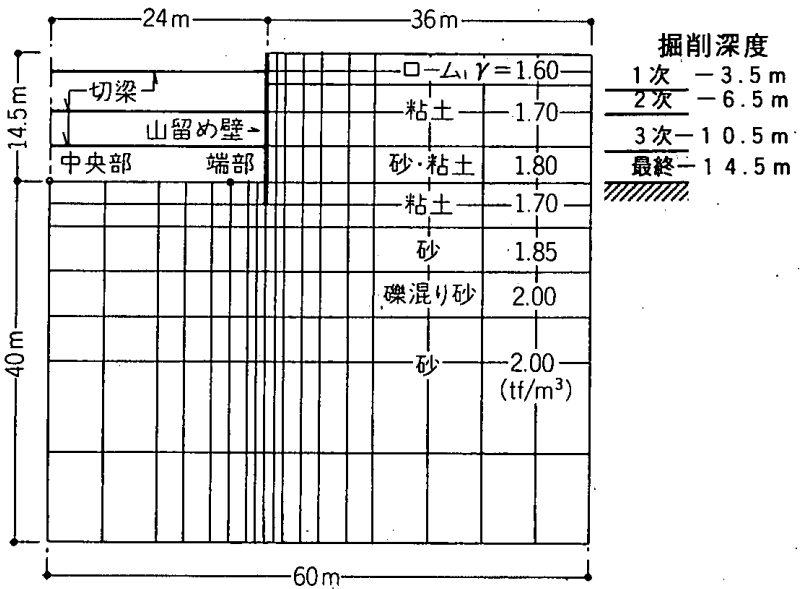

図一10 解析モデル 


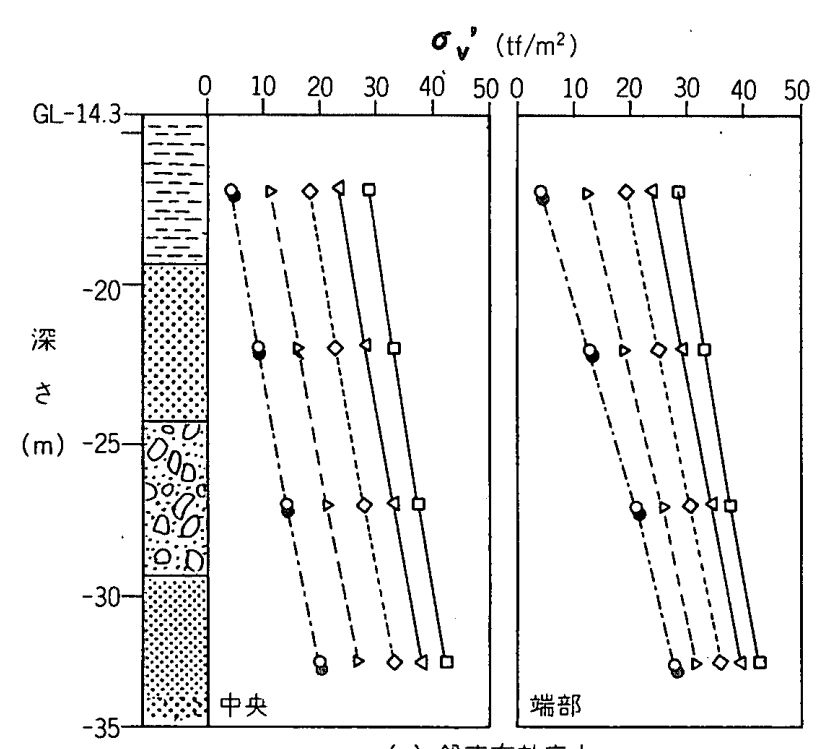

(a) 鉊直有効応力

$\sigma_{\mathrm{m}}^{\prime}\left(\mathrm{tf} / \mathrm{m}^{2}\right)$

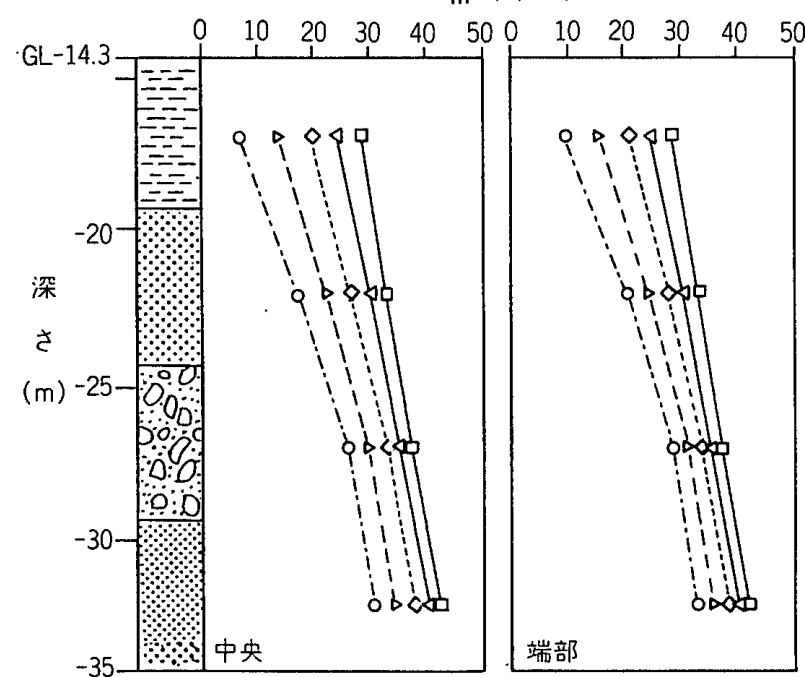

(b) 平均有効応力

口掘削前 $\triangleleft-$ 一次 $\diamond$ 三次 $\triangleright$ 三次 $\bigcirc$ 掘削終了時 ○掘削終了時：スタインブレナー

图一11掘削による地中応力の変化

$\sigma_{m}^{\prime}$ の解析値を図一11 に示した。 $\sigma_{v}^{\prime}$ および $\sigma_{m}^{\prime}$ ともに掘 削の進行に伴って減少しており, その減少量は端部より も中央部が大きい。また， $\sigma_{v}^{\prime} に$ 比べて $\sigma_{m}^{\prime}$ が大きく，掘 削に伴う水平応力の減少量は鉛直応力の減少量よりも小 さいことが分かる。

図一11(a)には，図一7において実測の鉛直変形量か らEを求めるのに用いたスタインブレナーの弾性近似解 によって計算した掘削終了時点の $\sigma_{v}^{\prime}$ も示した。スタイ ンブレナーの弾性近似解は FEM 解析値とほとんど差 がなく, スタインブレナーの弾性近似解による掘削底面 下の鉛直応力の計算値の誤差は少ないものと考えられる。 5.2 地中応力之微小ひずみ時のヤング係数の関係

$\mathrm{K}$ ビルの各掘削段階に測定したせん断波速度 $V s^{12)}$ と 図一11の $\sigma_{v}^{\prime}$ および $\sigma_{m}^{\prime}$ の関係を図一 12 に示した。VS は掘削による地中态力の減少により低下しており，Vs
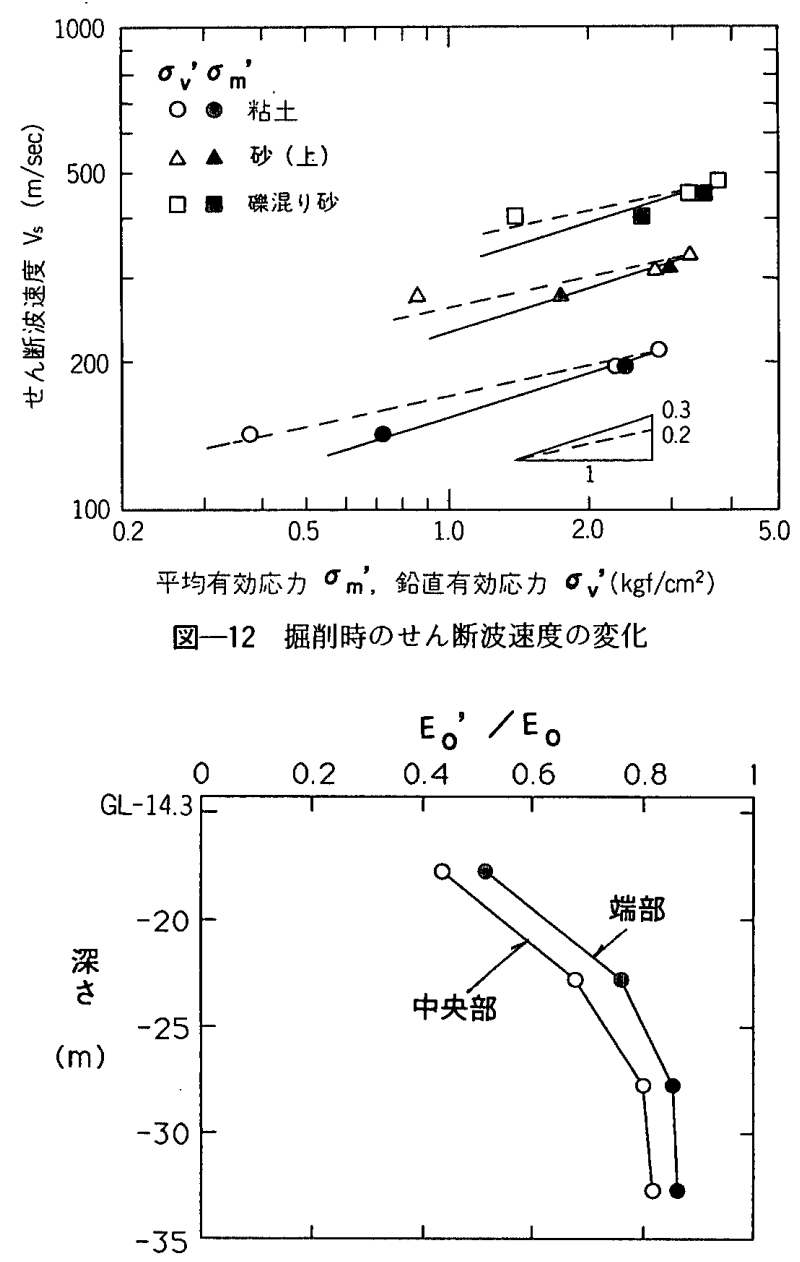

図一13 掘削前と掘削後のヤング係数の比

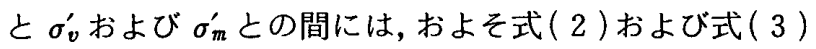
の関係がある。

$$
\begin{aligned}
& V s=\alpha \cdot \sigma_{v}^{0.2} \\
& V s=\beta \cdot \sigma_{m}^{0.3} .
\end{aligned}
$$

ここに, $\alpha, \beta$ : 地盤によって異なる係数

$V s$ が拘束圧に依存することは室内試験により既に確認 されているが(15),16), 図一12 は同じ性状を示すことを原 位置の測定から明らかにしたものである。

式（2）, 式（3）および前述の式（1）に基づき, 掘削時の微小ひずみ時のヤング係数 $E_{0}^{\prime}$ は式 $(4)$ また は式（5）によって表せる。

$$
\begin{array}{r}
E_{0}^{\prime}=2(1+\nu) \gamma \cdot V s_{0}^{2}\left(\sigma_{v}^{\prime} / \sigma_{v 0}^{\prime}\right)^{0.4} / g \cdots \\
E_{0}^{\prime}=2(1+\nu) \gamma \cdot V s_{0}^{2}\left(\sigma_{m}^{\prime} / \sigma_{m 0}^{\prime}\right)^{0.6} / g \cdots \\
こ こ に, \sigma_{v 0}^{\prime}, \sigma_{m 0}^{\prime}: \text { 掘削前の地中応力 } \\
\sigma_{v}^{\prime}, \quad \sigma_{m}^{\prime}: \text { 掘削時の地中応力 }
\end{array}
$$

したがって, 掘削前と掘削時の地中応力を求めることに よって，掘削前の地盤のせん断波速度 $V s_{0}$ から掘削途 中あるいは掘削終了後の微小ひずみ時のヤング係数 $E_{0}^{\prime}$ を求めることができる。

\section{3 掘削平面の中央部と端部のヤング係数比の違い}

地盤の Vs は掘削による地中応力の減少により低下す る。図一11(b) の $\sigma_{m}^{\prime}$ の分布に基づき, 式 ( 5 ) を用い, 


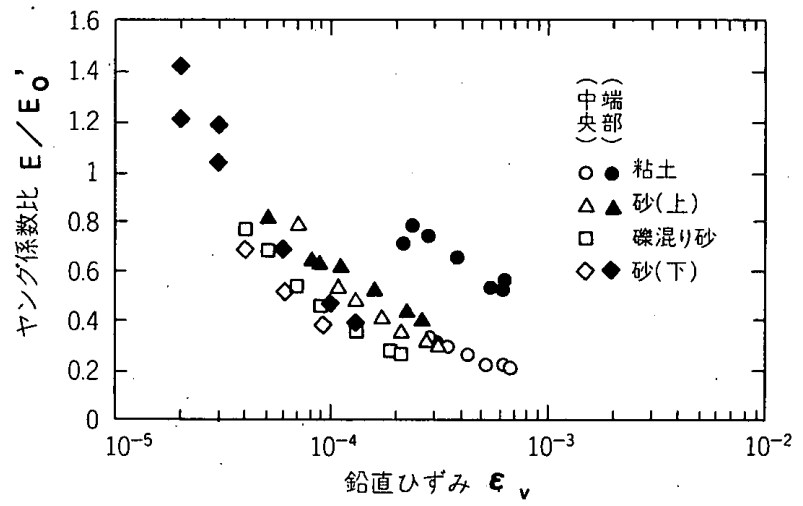

図一14.掘削後の $E_{0}^{\prime}$ を用いた中央部と端部のヤング係数比の 比較 (構築時)

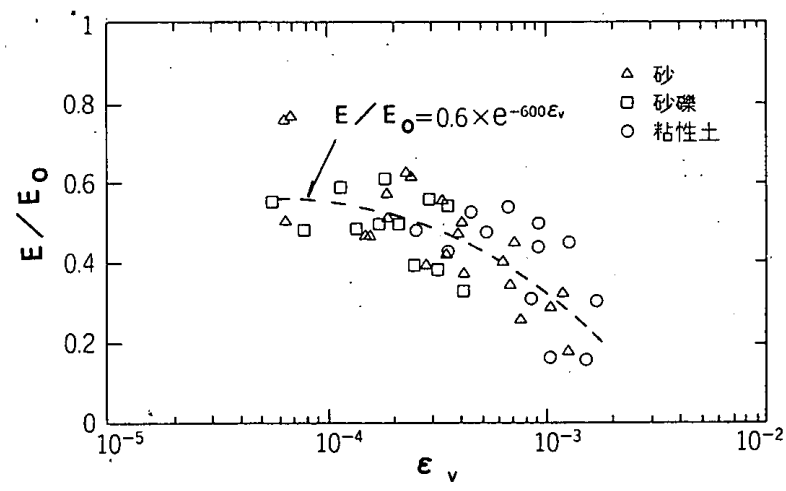

図一15 ヤング係数比と鉛直ひずみの関係（掘削時）

掘削終了時点之掘削前の微小ひずみ時のヤング係数の比 $E_{0}^{\prime} / E_{0}$ を求めたのが図一13であり，中央部の $E_{0}^{\prime} / E_{0}$ は 端部に比べて小さい值になる。したがって，構築時につ いては，事前調査による $V s_{0}$ から求めた微小ひずみ時 のヤング係数 $E_{0}$ の代わりに平面位置で異なる掘削終了 時点の $E_{0}^{\prime}$ を基準にしてヤング係数比 $E / E_{0}^{\prime}$ の性状につ いて検討するのが適切である。

掘削終了時点の中央部之端部の各地層の $E_{0}^{\prime}$ を用い て, 図一 $9(b) \cdot$ 構築時の $E / E_{0}$ と $\varepsilon_{v}$ の関係を書き直し たのが図一14である。中央部と端部の $E / E_{0}^{\prime}$ と $\varepsilon_{v}$ の関 係の差は，掘削底面直下の粘土層の場合を除き，図一9 (b) の $E / E_{0}$ 之 $\varepsilon_{v}$ の関係の場合より小さい。平面位置 により異なる掘削終了時の $E_{0}^{\prime}$ を用いた場合; 構築時の 中央部と端部のヤング係数比 $E / E_{0}^{\prime}$ 之鉛直ひずみ $\varepsilon_{v}$ の 関係はほぼ等しい関係を示すものと考えられる。

\section{4 ヤング係数比之鉛直ひずみの関係}

掘削時のヤング係数比 $E / E_{0}$ と鉛直ひずみ $\varepsilon_{v}$ の関係 について，図一9(a) の K.ビルにおける掘削中央部の結 果に，筆者らがその他の建物の掘削平面のほぼ中央で測 定した結果 ${ }^{9}$ も加えて，地盤種類別に図一15に示した。 地盤の種類による明確な差はなく, $E / E_{0}$ と $\varepsilon_{v}$ の関係 はおよそ式（6）で表される。

$$
E / E_{0}=0.6 \times e^{-600 \varepsilon_{0}}
$$

また，図一16 は，掘削終了時の $E_{0}^{\prime}$ を用いたときの，

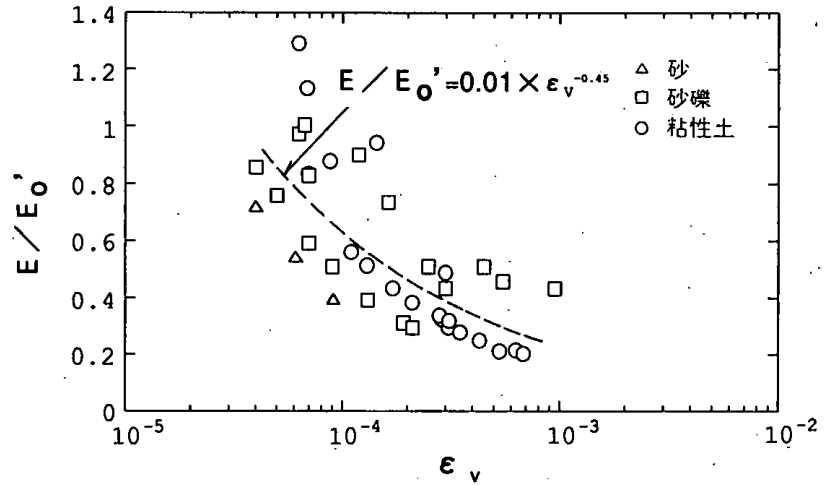

图一16 ヤング係数比と鉛直ひずみの関係（構築時）

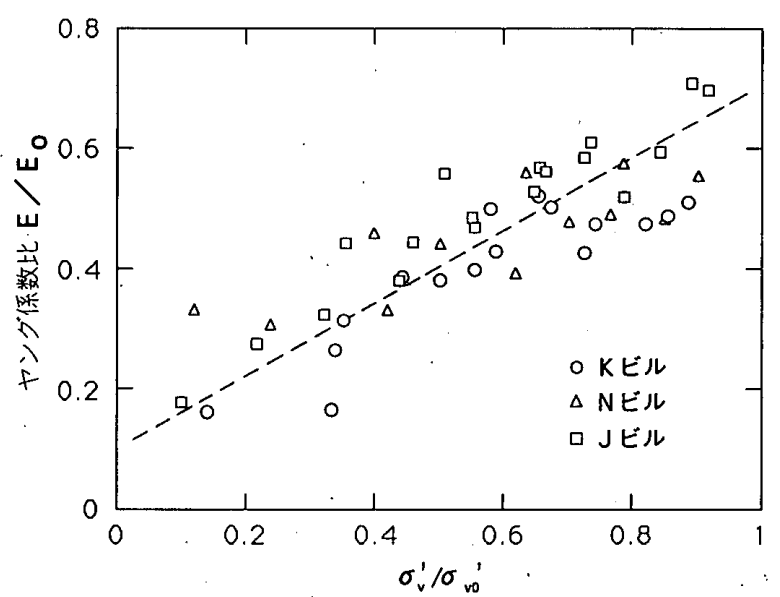

図-17 鉛直有効応力比とヤング係数比の関係

構築時の掘削中央部におけるヤング係数比 $E / E_{0}^{\prime}$ と $\varepsilon_{v}$ の関係であり, 図一 15 と同様に K ビル以外の結果 ${ }^{9}$ も併 せて地盤種類別に示したものである。構築時の $E / E_{0}^{\prime}$ と $\varepsilon_{v}$ の関係はおよそ式·( 7$)$ で表される。

$$
E / E_{0}^{\prime}=0.01 \times \varepsilon_{v}^{-0.45}
$$

ヤング係数比は掘削時および構築時ともに $\varepsilon_{v}$ の増加 に伴って低下する。しかし, 掘削時の $E / E_{0}$ と $\varepsilon_{v}$ の関 係と構築時の $E / E_{0}^{\prime}$ と $\varepsilon_{v}$ の関係は異なる。これは, 掘 削時は $\varepsilon_{v}$ の増加による $E$ の低下に加え, 地中応力の減 少により $E$ がさらに低下し， $E / E_{0}$ の低下率が増加す るためと考えられる。一方, 構築時は地中応力の増加に よって $E$ の低下率は逆に減少するため $E / E_{0}^{\prime}$ と $\varepsilon_{v}$ の関 係は凹な性状を示すものと考えられる。図一15および 図一16 は，地盤のヤング係数が地盤のひずみに依存す るとともに，施工時の地中応力の影響を受ける，地盤の ヤング係数の性状を明確に表したものと言える。

事前調查による地盤のせん断波速度と, 式（6）およ び式（7.）のヤング係数比と鉛直ひずみの関係とから, 鉛直変位の実測值からヤング係数 $E$ を計算するのに用 いた前述のポアソン比を仮定して, 繰返し計算を行うこ とにより, 実状に合った各掘削および構築時点の地盤ヤ ング係数を推定することが可能である。

なお, 図一17 は掘削時の中央部における鉛直有効応 力 $\sigma_{v}^{\prime}$ と掘削前の鉛直有効応力 $\sigma_{v 0}^{\prime}$ の比 $\sigma_{v}^{\prime} / \sigma_{v 0}^{\prime}$ とヤング 
係数比 $E / E_{0}$ の関係である。 $\sigma_{v}^{\prime} / \sigma_{v 0}^{\prime}$ と $E / E_{0}$ の間には ほぼ直線関係があり，E/E。 はおよそ式 $(8)$ で表せる。

$$
E / E_{0}=0.6 \cdot \sigma_{v}^{\prime} / \sigma_{v 0}^{\prime}+0.1 \cdot
$$

各掘削時点の地盤の変形量を求める際の地盤のヤング係 数については, 事前調查による地盤のせん断波速度と, 掘削前の $\sigma_{v 0}^{\prime}$ および掘削時の $\sigma_{v}^{\prime}$ とから式 (8) により 容易に推定することができる。

\section{6. 結 論}

考案した新しい形式の層別沈下計を用いて, 直接基礎 により支持された建物の施工時に支持地盤の鉛直変位を 測定した。掘削および建物構築開始時点からの鉛直変位 から，スタインブレナーの弾性近似解を用いて支持地盤 のヤング係数 $E$ を求め, $E$ と事前調查によるせん断波 速度 $V s_{0}$ から求めた微小ひずみ時のヤング係数 $E_{0}$ との 比（ヤング係数比 $E / E_{0}$ ) の性状について明かした。

また, 層別沈下計の各変位計部分に取り付けた加速度 計によって掘削時の地盤のせん断波速度Vs の変化を測 定し，地中応力とせん断波速度の関係を明らかにした。

上述の測定により, 支持地盤のヤング係数の推定方法 にかかわる次のことが明らかになった。

（1）地盤のせん断波速度Vs は掘削による地中応力の 減少により低下し, 両者の関係は式 (2), および式 (3) で表せる。したがって, 建物構築時については, 事前調 查時の $V s_{0}$ から求めた $E_{0}$ の代わりに, 式 $(2)$ または 式（3）により求めた掘削終了時点の微小ひずみ時のヤ ング係数 $E_{0}^{\prime}$ を基準にするのが適切である。

(2) 掘削時の $E / E_{0}$ と $\varepsilon_{v}$ の関係之構築時の $E / E_{0}^{\prime}$ 之 $\varepsilon_{v}$ の関係は異なり, 掘削時に関しては式 $(6)$, 構築時 に関しては式（7）で表せる。

（3）掘削終了後の地中応力分布は平面位置により異な るので, 建物構築時に関しては平面位置により異なる $E_{0}^{\prime}$ を用いるのが望ましい。

（4）掘削時の地盤の鉛直有効応力之掘削前の鉛直有効 忘力の比 $\sigma_{v}^{\prime} / \sigma_{v 0}^{\prime}$ と $E / E_{0}$ の間にはおよそ式 $(8)$ の関 係があり, 掘削時の $E$ については掘削前之後の鉛直有効 応力を求めることによって容易に推定することができる。

\section{7. おわりに}

施工時に行った支持地盤の鉛直変位の測定結果から地 盤のヤング係数の性状について述べた。得られたヤング 係数比と鉛直ひずみの関係などは実測に基づいたもので あるので実際の現象とよく対応し, 支持地盤のヤング係 数の推定に対する適用性は高いものと考えられる。

\section{謝 辞}

今回の測定に用いた層別沈下計の作製にあたっては， 清水建設東京支店技術部 天野 賢氏ならびに自動制御 技術研究所 谷口勝利氏に多大な御協力を頂いたことを
感謝いたします。また，実测計画と実施にあたっては清 水建設設計本部構造設計部ならびに建築本部の方々の御 協力, 御支援頂きましたことに末筆ならが感謝の意を表 します。

\section{参考文献}

1）日本建築学会：建築基礎構造設計指針，pp. 146 154, 1988.

2) Burland J. B. Burbidge M. C. : Settlement of Foundations on Sand and Gravel, Proc. Institution of Civil Engineers, Part 1, Vol.78, pp. 1325 1381, 1985.

3）植下 協, 松井克俊, 大岡 武, 永瀬信一：地盤の挙動 計測による建築基礎の合理化の例，土質工学会諭文報告 集, Vol. 13, No. 3, pp. 87 95, 1973.

4）笹尾 光：東京における超高層ビルの沈下性状, 鹿島建 設技術研究年報, Vol. 24, pp. 141 146, 1975.

5）玉野富男, 福井 聡, 村上 仁, 門田俊一：土留め掘削 底部地盤におけるリバウンドの力学挙動解析, 土木学会 論文集, 第 418 号, pp. 221 230, 1990.

6）秋野矩之：地盤の剛性評価之建物の沈下予測, 日本建築 学会構造系論文報告集, 第 412 号, pp. 109 119, 1990.

7）玉置克之，宮本武司：砂層の沈下量推定における結果の 適用性，平板載荷試験に関するシンポジウム発表論文集， pp. 51 58, 1979.

8）玉置克之, 土屋 勉：施工時の建物の沈下実測結果およ び沈下推定に対する現位置試験結果などの適用性の検討， 清水建設研究所報, 第 35 号, pp. 1 9, 1982.

9）玉置克之, 桂 豊, 岸田了：施工時の鉛直変位測定 に基づく支持地盤のヤング係数，清水建設研究報告，第 55 号, pp. $11 \sim 20,1992$.

10）玉置克之, 西尾伸也, 後藤 茂, 天野 賢: 層別沈下計 測による支持地盤の変形係数, 第 23 回土質工学研究発表 会発表講演集, pp. 1245 1246, 1988.

11）西尾伸也，玉置克之，佐藤正義，天野賢：掘削に伴う 地盤のS 波速度の変化, 第 23 回土質工学研究発表会発表 講演集, pp. $641 \sim 644,1988$.

12）西野伸也，桂豊，玉置克之，森誠二：掘削に伴う 支持地盤の変形性状（その3)一世ん断波速度から求めた 支持地盤の変形係数, 第 25 回土質工学研究発表会発表講 演集, pp. 1137 1138, 1990.

13) Terzaghi K. : Theoretical Soil Mechanics, Wiley, pp. 423 425, 1943.

14）玉置克之, 岸田 了, 桂 豊, 社本康広：支持地盤の ヤング係数の推定方法, 清水建設研究報告, 第 55 号, pp. 21 29, 1992.

15) Hardin B. O. \& Richart F.E., Jr. : Elastic Wave Velocities in Granular Soils, Journal of the Soil Mechanics and Foundations Division, ASCE, Vol.89, No. SM 1, pp. 33 65, 1963.

16) Nishio S. and Tamaoki, K. : Measurement of Shear Wave Velocities in Diluvial Gravel Samples under Triaxial Conditions, Soils \& Foundations, Vol.28, No. 2, pp. 35 48, 1988.

(1992 年 8 月 21 日原稿受理, 1993 年 1 月 27 日採用決定) 